\title{
Alkalophilic Protease Producing Bacteria and Some Biotechnological Potentials
}

\section{Muddasir Hassan Abbasi ${ }^{1}$, Rabia Mehmood ${ }^{2}$, Muhammad Babar Khawar ${ }^{2,3,4,5, *}$, Hafiza Nabeela Amaan ${ }^{6,7}$,} Amin Arif2, Tahaa Saeed ${ }^{2,8}$, Mussarat Rafiq ${ }^{2}$

${ }^{1}$ Department of Zoology, University of Okara, Pakistan.

${ }^{2}$ Department of Zoology, University of the Punjab, Q-A- Campus, Lahore, Pakistan.

${ }^{3}$ Department of Zoology, University of Central Punjab, Lahore, Pakistan.

${ }^{4}$ State Key Laboratory of Stem Cell and Reproductive Biology, Institute of Zoology, Chinese Academy of Sciences, Beijing, China.

5 University of Chinese Academy of Sciences, Beijing, China.

${ }^{6}$ Institute of Clinical Nutrition \& Dietetics, Gulab Devi Educational Complex, Lahore, Pakistan.

${ }^{7}$ Gulab Devi Chest Hospital, Lahore-Pakistan.

${ }^{8}$ Department of Biology, Syed Babar Ali School of Science and Engineering, Lahore University of Management Sciences, Lahore, Pakistan.

\section{ABSTRACT}

Background: Use of extremophiles is a hot topic in the field of biotechnology for their immense potential and applications in multiple industries.

Objectives: The present review aims to sum up the potential applications of alkalophilic protease-producing bacteria and their optimized growth requirement. The isolation, characterization, and optimization of various isolates (especially of genus Bacillus) from different harsh niches, including soil samples from deserts and soil having decaying matters, wastewaters from industries, soda lakes, and alkaline springs have been reported in this review.

Methodology: All the relevant papers published from 2013-2020 were looked over numerous sources like Google Scholar, Medline, PubMed, Research Gate, Science Direct, Scopus and Web of Science.

Results: Most of the microbial life found in extreme alkaline habitats are found to form a variety of enzymes and an array of other substances of biotechnological interests. These enzymes, especially proteases, are exploited in industries globally because of their ability to withstand rigorous industrial reactions and conditions.

Conclusion: Though a number of alkalophilic protease-producing bacteria have been isolated, still a large number of these microorganisms are unidentified. The current demand for biotechnological products from them appeals to the need for isolation of unidentified bacteria.

$\begin{array}{lcl}\text { Keywords } & \text { *Address of Correspondence } & \text { Article info. } \\ \text { Alkalophilic, Biotechnological potential, } & \text { mbk@ioz.ac.cn, } & \text { Received: March 18, 2020 } \\ \text { Extremophiles, Industries, Protease. } & \text { babarkhawar@yahoo.com } & \text { Accepted: November 22, 2020 }\end{array}$

Cite this article: Abbasi MH, Mehmood R, Khawar MB, Amaan HN, Arif A, Saeed T, Rafiq M.

Alkalophilic Protease Producing Bacteria and Some Biotechnological Potentials. RADS J Biol Res

Appl Sci. 2020; 11(2):136-143.

This is an Open Access article distributed under the terms of the Creative Commons Attribution License (http://creativecommons.org/licenses/by/4.0), which permits unrestricted use, distribution, and reproduction in any medium provided the original work is properly cited.

\section{INTRODUCTION}

Over the past few decades, scientists have become interested in the extraordinary organisms that can survive in severe and harsh environments where no life form can sustain except extremophiles. Microenvironments or niches inhabited by these organisms are once considered hostile for life which could have extreme $\mathrm{pH}$ conditions, 
ice, hot springs, concentrated salt solutions, high pressure, toxic waste deposits, organic solvents, heavy metals, oxygen scarcity, variety of radiations and various combinations thereof. The power to adapt extreme niches could be imagined by the fact that some extremophiles have been isolated from $\mathrm{pH}$ ranges $0-12.8$, from ice-cold habitats $\left(-20^{\circ} \mathrm{C}\right)$ to hydrothermal vents $\left(122^{\circ} \mathrm{C}\right)$, $100-110 \mathrm{MPa}$ pressure as well as from deep-sea $(10 \mathrm{~km})$ and earth's crust at the depth of $6.7 \mathrm{~km}$. Additionally, extremophiles adapted for more than one extreme conditions are referred to as polyextremophiles ${ }^{1,2}$.

\section{Extremophiles: A Hot Debate}

Since the discovery of extremophiles, these organisms are of the most concerning issue of biotechnology because of their adaptability and survival in harsh conditions. Because of such complex physiology, they are exploiting their potential at the industrial level. The discovery of renowned enzyme Taq polymerase from an extremophile Thermus aquaticus employed in PCR is one of the examples, which bring a revolution in the field of gene cloning. After this discovery, extremophiles laid down the base of a large group of extremophilic researchers as well as was thrown into gear a new area of research which resulted in the "International Society for Extremophiles", and even a journal founded by Koki Horikoshi namely "Extremophiles". The importance of extremophiles could be realized by the fact that separate conferences on extremophiles are conducted in different parts of the world 3 .

Recently, some books have been published regarding the whole spectrum of extremophiles which deals with the lifestyle, biochemistry, genomics, physiology, and even the regulation of their metabolism. Research on extremophiles is plentiful and is as diverse as the extremophilic microbes themselves, so the information regarding extremophiles is beyond the scope of this review which restricts us, to sum up with few examples ${ }^{4-6}$.

\section{Classification of Extremophiles}

The classification is based upon the circumstances in which they survive and grow. These include psychrophiles, halophiles, alkaliphiles, acidophiles, basophils, thermophiles, and hyperthermophiles which show optimal growth at low temperatures, high salt concentrations, basic or acidic $\mathrm{pH}$, under pressure and high or very high temperatures, respectively 7,8 .

\section{Alkaliphiles / Alkalophiles}

Alkaliphiles, show the ability to grow in various habitats having a pH range of 9.0 to 11.0 and show optimum growth at $\mathrm{pH} 10.0$. They could be isolated from common habitats like garden soil perhaps due to momentary alkaline conditions resulting from biological activities including ammonification or sulfate reduction. In contrast, other potential sources of alkaliphiles include soil samples from deserts and soil having decaying matters, wastewaters from industries, soda lakes, and alkaline springs ${ }^{9,10}$. This class of extremophiles is of keen interest because of their bioenergetic, environmental, and industrial potentials ${ }^{11}$. These microbes are found to produce a rich collection of products including cyclodextrin, wood pulp, WA 52 (macrolide antibiotic) sugar cleaning agents ${ }^{12-15}$, and are sources of active enzymes e.g. proteases, amylases, cellulases, and xylanases which work optimally in alkaline conditions. These enzymes have a major impact and biotechnological potential in various commercial applications and industrial processes e.g. production of detergents ${ }^{16,17}$. Industrial synthesis of products from alkaliphiles is so far inadequate to meet up the demands. Apart from significant diversity, many more of them remain to be hidden from unexplored remote environments. The aims current work is to go over the potential applications of alkalophilic protease producing bacteria and their optimized growth requirements.

\section{Alkaliphiles: A Rich Source of Proteases}

Enzymes are bio-catalysts that have marvellous applications in several industries including food, detergent formulations, metal recovery, leather processing etc. Extremophilic enzymes can withstand and catalyze reactions in extreme environments and found to have potential applications in above-mentioned industries ${ }^{18}$. Up to now, a vast array of more than three thousand (3000) enzymes have been reported and exploited in various industrial applications. This immense number is still not enough to meet the current demand because most known enzymes do not survive in extreme industrial reaction conditions, which results in drawing the attention for the isolation and optimization of microbes which can flourish 
in that hostile environment. Microorganisms or microbial sources account for $90 \%$ of the enzymes produced for industrial purposes ${ }^{19}$.

Proteases (EC 3.4.21-24 and 99; peptidyl-peptide hydrolases) are among three major classes of enzymes which have been studied extensively and play a fundamental role in cellular metabolic processes including cell growth and differentiation. Proteases hydrolyze proteins, termed as proteolysis; results in the formation of protein, peptide fragments, and free amino acids ${ }^{20-22}$. These enzymes are not only biologically important but also industrially. Proteases are ruling and exploiting globally on an industrial scale sc $^{23}$ as they can withstand severe and harsh conditions like a wide range of $\mathrm{pH}$, extreme temperature, high salts, organic solvents, detergents, and denaturing agents ${ }^{24}$. Proteases play a significant role in various industrial applications viz, brewing, meat, photographic, leather, dairy ${ }^{25}$, detergent, paper, and pulp and silk industries ${ }^{26}$, food, and pharmaceutical as well as in bioremediation processes $^{27-29}$.

Proteases account for about the $2 / 3(60-65 \%)$ share of the total enzyme market worldwide and this value is thought to be increased in near future. The dominance of this enzyme could be estimated by the fact that protease sales globally were estimated to be $\$ 1$ billion in $1998^{30}$.

\section{Bacillus sp. and Alkalophilic Enzyme Production}

The major assemblage of alkaliphiles is found in the bacterial genera Bacillus, Micrococcus, and Pseudomonas but major contributions is of Bacillus. Important roles played by Bacillus spp. have a long history of more than 1000 years ${ }^{11}$. The alkaline proteases produced by different Bacillus spp. are of commercial importance as these can survive a wide range of temperature and $\mathrm{pH}$ for multiple applications. A variety of them has been isolated and characterized ${ }^{31-33}$. A huge list of microbial strains of Bacillus spp. i.e. Bacillus pseudofirmus, Bacillus subtilis, Bacillus. licheniformis, and Bacillus cereus has been exploited at the industrial scale for their catalytic role (Table 1) ${ }^{34-36}$. Bacillus. flexus, Bacillus cereus, Bacillus pseudofirmus, Bacillus pseudoalkalophilus, make up a toolbox of industrial enzymes and are alkalophilic protease producers showing optimum growth at $\mathrm{pH} 10^{37}$.
Table 1. Different Alkaline Protease-Producing Bacillus Species Exploited at the Industrial Scale for Their Catalytic Role.

\begin{tabular}{clc}
\hline S. No. & Bacillus sp. & Reference \\
\hline 1. & B. stearothermophilus & 33 \\
\hline 2. & B. alcalophilus TCCC11004 & 34 \\
\hline 3. & B. subtilis AKRS3 & 35 \\
\hline 4. & B. pseudofirmus SVB1 & 36 \\
\hline 5. & $\begin{array}{l}\text { B. cereus, B. flexus, B. } \\
\text { pseudoalcalophilus }\end{array}$ & 37 \\
\hline 6. & B. licheniformis & 38 \\
\hline 7. & B. thermoruber BT2T & 39 \\
\hline 8. & Bacillus sp. strain B18' & 40 \\
\hline
\end{tabular}

The optimum enzyme activity of extracellular protease production from Bacillus cereus strain CA15 was noted in the medium containing skimmed milk and starch $1 \%$ with $0.6 \% \mathrm{MgSO}_{4} .7 \mathrm{H}_{2} \mathrm{O}$ at $\mathrm{pH} 8.0$ and $35^{\circ} \mathrm{C}$. This bacterium was found to be stable against various commonly available detergents and also showed maximum enzyme production in the stationary phase ${ }^{41}$. A similar attempt was done in which 39 isolates were collected from industrial waste from Lahore-Pakistan. The screening was performed on Luria broth medium agar with $\mathrm{pH}$ ranging from 8 to 10. Thirty-two (32) isolates were selected but only 20 were found to meet the above-mentioned criteria. Among 20 isolates, BCTL-147 was characterized as genus Alcaligenes which was then optimized for growth at $\mathrm{pH} 10$ and $35^{\circ} \mathrm{C}^{42}$. In a study, Bacillus halodurans were used to optimize the production of the alkaline enzyme at different conditions of $\mathrm{pH}$ value, temperature, aeration, and incubation time along with different sources and concentrations of carbon, nitrogen, and metals. The optimum activity was observed at $37^{\circ} \mathrm{C}$ with $200 \mathrm{rpm}$ agitation in a medium containing $(\mathrm{g} / \mathrm{L})$ lactose 15 , soybean 6 together with a $5 \mathrm{mM}$ mixture of trace elements like $\mathrm{Mg}, \mathrm{Ca}$, and $\mathrm{Mn}^{43}$. Recently, 12 bacteria were isolated from Lonar soda lake, District Buldhana, MaharashtraIndia. These isolates LAP42 were characterized as grampositive rods at optimum growth conditions of $\mathrm{pH} 10$ and $30^{\circ} \mathrm{C}$ in $1 \% \mathrm{NaCl}$. The crude enzyme was found to work 
optimally at similar pH but at $65^{\circ} \mathrm{C}$, augmented with $5 \mathrm{mM}$ $\mathrm{CaCl}_{2}$ and $\mathrm{MgSO}_{4}$. This enzyme was well-suited to use in the detergent industry ${ }^{44}$. In Hungary, from alkaline soda lakes, three strains of halophilic and alkaliphilic nature (K1-5 ${ }^{\top}, \mathrm{K} 1-10$, and $\left.\mathrm{B} 1-1\right)$ were isolated, optimized, and characterized with maximum growth at basic $\mathrm{pH}$ 9.0-10.0 and $3-7 \%(\mathrm{w} / \mathrm{v})$ sodium chloride. These strains were gram-positive straight rods, aerobic, catalase-positive and oxidase-negative. Multi-phasic characterization of the isolates indicates a novel species of Bacillus, Bacillus aurantiacus $s p$. nov., ${ }^{45}$. Similarly, from dairy industry soil $(\mathrm{pH}$ 9.86) a Bacillus sp. was isolated. Upon optimization and characterization, the strain was found to produce extracellular alkaline protease optimally at $\mathrm{pH}$ 8-11, temperature ranging after $25-50^{\circ} \mathrm{C}$ and was somewhat halophilic. 16S rDNA sequencing confirmed the isolated species as Bacillus flexus and it was $99 \%$ identical with related existing strain viz., Bacillus flexus accession No. JN033557.1, FJ948078.1, EF157300.1 retrieved from the databases Gene bank, NCBI, and Ribosomal Database Project ${ }^{46}$. Eighteen isolates were screened for alkaline protease production from various microenvironments, only six out of eighteen isolates showed efficient enzyme production. Among them, two isolates were recognized as Bacillus pumilus $p 1$ and Staphylococcus auricularis $p 18$ which showed noteworthy enzyme activity. Upon characterization, they showed optimal enzyme-producing activity at 72 hours incubation period, $\mathrm{pH} 8.0-9.0$ and at $45^{\circ} \mathrm{C}$. Nitrogen sources were optimized and reported as $0.9 \%$ and $0.5 \%$ for peptone and yeast extract, respectively for both strains. Bacillus pucilum and Staphylococcus auricularis showed $0.065 \mathrm{U} / \mathrm{ml}$ and $0.038 \mathrm{U} / \mathrm{ml}$ enzyme activity, respectively when assayed using the tyrosine-casein method. The potent applications were found as dehairing and depilating of raw leather, metal recovery $(\mathrm{Ag})$ from $\mathrm{X}$-ray photographic films and bacterial bio-film degradation ${ }^{47}$.

Table 2. Some Examples of Alkaline Protease-Producing Bacillus Species and Their Cultivation Media.

\begin{tabular}{|c|c|c|c|}
\hline S. No. & Species & Medium & References \\
\hline 1 & Bacillus sp. JB-99 & $\begin{array}{l}\text { Citric acid, } \quad 10.0(\mathrm{~g} / \mathrm{l}) ; \quad \mathrm{NaNO}_{3}, \quad 10.0(\mathrm{~g} / \mathrm{l}) ; \quad \mathrm{K}_{2} \mathrm{HPO}_{4}, \quad 5.0(\mathrm{~g} / \mathrm{l}) ; \\
\mathrm{MgSO}_{4} .7 \mathrm{H}_{2} \mathrm{O}, \quad 0.3(\mathrm{~g} / \mathrm{l}) ; \quad \mathrm{CaCl}_{2} .2 \mathrm{H}_{2} \mathrm{O}, \quad 0.2(\mathrm{~g} / \mathrm{l}) ; \mathrm{NaCl}, 5.0(\mathrm{~g} / \mathrm{l}) \text { and } \\
\mathrm{Na}_{2} \mathrm{CO}_{3}, 10.0(\mathrm{~g} / \mathrm{l}) \text { at pH } 10.0 .\end{array}$ & 49 \\
\hline 2 & Bacillus pseudofirmus AL-89 & $\begin{array}{l}\text { Casein, } 10(\mathrm{~g} / \mathrm{l}) ; \text { peptone, } 5(\mathrm{~g} / \mathrm{l}) ; \text { yeast extract, } 1(\mathrm{~g} / \mathrm{l}) ; \mathrm{K}_{2} \mathrm{HPO}_{4}, 1(\mathrm{~g} / \mathrm{l}) ; \\
\mathrm{MgSO}_{4} \cdot 7 \mathrm{H}_{2} \mathrm{O}, 0.2(\mathrm{~g} / \mathrm{l}) ; \mathrm{CaCl}_{2}, 0.1(\mathrm{~g} / \mathrm{l}) ; \mathrm{Na}_{2} \mathrm{CO}_{3}, 10(\mathrm{~g} / \mathrm{l}) ; \text { and for agar } \\
\text { plates } 15 \mathrm{~g} / \mathrm{l} \text { agar was included. }\end{array}$ & 50 \\
\hline 3 & Bacillus sp. I-312 & $\begin{array}{l}\text { Soybean meal, } 15(\mathrm{~g} / \mathrm{l}) ; \text { wheat flour, } 10(\mathrm{~g} / \mathrm{ll}) ; \text { fructose, } 5(\mathrm{~g} / \mathrm{l}) ; \mathrm{K}_{2} \mathrm{HPO}_{4} \text {, } \\
4(\mathrm{~g} / \mathrm{l}) ; \mathrm{Na}_{2} \mathrm{HPO}_{4}, 1(\mathrm{~g} / \mathrm{l}) ; \mathrm{CaCl}_{2}, 0.05(\mathrm{~g} / \mathrm{l}) ; \mathrm{Na}_{2} \mathrm{CO}_{3}, 8(\mathrm{~g} / \mathrm{l}) \text { at } 32^{\circ} \mathrm{C} \text { for } \\
48 \text { hours incubation period with agitation of } 250 \mathrm{rpm} \text {. }\end{array}$ & 51 \\
\hline 4 & Bacillus sp. Ve1 & $\begin{array}{l}\text { Gelatin, } 10(\mathrm{~g} / \mathrm{l}) ; \text { casein enzymatic hydrolysate, } 10(\mathrm{~g} / \mathrm{l}) ; \mathrm{NaCl}(\mathrm{w} / \mathrm{v}) \text {, } \\
100(\mathrm{~g} / \mathrm{l}) \text { at } \mathrm{pH} 9 \text {. }\end{array}$ & 52 \\
\hline 5 & Bacillus sp. NPST-AK15 & $\begin{array}{l}\text { Fructose, } 20(\mathrm{~g} / \mathrm{l}) ; \text { yeast extract, } 7.5(\mathrm{~g} / \mathrm{l}) ; \mathrm{K} 2 \mathrm{HPO} 4, \quad 1.0(\mathrm{~g} / \mathrm{l}) ; \\
\mathrm{Mg} 2 \mathrm{SO} 4.7 \mathrm{H} 2 \mathrm{O}, 0.2(\mathrm{~g} / \mathrm{l}) ; \mathrm{NaCl} 50(\mathrm{~g} / \mathrm{l}) \text { and } \mathrm{Na} 2 \mathrm{CO} 3,10(\mathrm{~g} / \mathrm{l}) \text {. }\end{array}$ & 53 \\
\hline 6 & Bacillus No. 221 & $\begin{array}{l}\text { Glucose, } 10(\mathrm{~g} / \mathrm{l}) ; \text { polypeptone, } 5(\mathrm{~g} / \mathrm{l}) ; \text { Difco yeast extract, } 5(\mathrm{~g} / \mathrm{l}) \text {; } \\
\mathrm{K}_{2} \mathrm{HPO}_{4}, 1(\mathrm{~g} / \mathrm{l}) ; \mathrm{MgSO} 4.7 \mathrm{H}_{2} \mathrm{O}, 0.2(\mathrm{~g} / \mathrm{l}) ; \mathrm{Na}_{2} \mathrm{CO}_{3}, 10(\mathrm{~g} / \mathrm{l}) \text {. }\end{array}$ & 54 \\
\hline 7 & $\begin{array}{l}\text { Bacillus alcalophilus subsp. } \\
\text { halodurans KP1239 }\end{array}$ & $\begin{array}{l}1 \% \text { sodium citrate, } 0.3 \% \text { yeast extract and } 0.3 \% \mathrm{KH}_{2} \mathrm{PO}_{4}, \mathrm{pH} 7.6 \\
\text { after } 24 \mathrm{~h} \text { of cultivation }\end{array}$ & 55 \\
\hline 8 & Bacillus licheniformis & 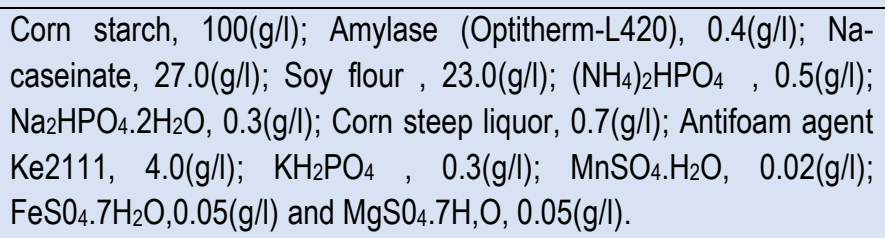 & 56 \\
\hline 9 & Bacillus sphaericus & $\begin{array}{l}\text { Glucose, } 10.0(\mathrm{~g} / \mathrm{l}) ; \text { biopeptone, } 5.0(\mathrm{~g} / \mathrm{l}) ; \text { yeast extract, } 5.0(\mathrm{~g} / \mathrm{l}) \text {; } \\
\mathrm{KH}_{2} \mathrm{PO}_{4}, 1.0(\mathrm{~g} / \mathrm{l}) ; \mathrm{MgSO}_{4} \cdot 7 \mathrm{H}_{2} \mathrm{O}, 0.2(\mathrm{~g} / \mathrm{l}) \text { and } \mathrm{Na}_{2} \mathrm{CO}_{3}, 10.0(\mathrm{~g} / \mathrm{l}) \text {. }\end{array}$ & 57 \\
\hline
\end{tabular}


In a related study, a thermophilic Bacillus sp. GUS1 was identified from a soil sample from a citrus garden. Detection by SDS-PAGE and zymogram analysis confirmed the production of three proteases which were stable in the alkaline $\mathrm{pH}$ range (8.0-12.0), and optimum temperature $\left(70^{\circ} \mathrm{C}\right)$. The enzymes retained $100 \%$ of their activities at these extreme values of $\mathrm{pH}$ and temperature. Addition of phenylmethylsulfonyl fluoride (PMSF) inhibited the presence of 2-mercaptoethanol however, iodoacetate does not affect the enzyme activities. SDS and EDTA affected the protease activities somewhat, but the presence of $\mathrm{Ca}^{2+}$ showed no effect on their activity. This work inferred that these proteases were not metalloproteases, but $\mathrm{Ca}^{2+}$-independent serine alkaline proteases ${ }^{48}$. EDTA resistance and not requiring $\mathrm{Ca}^{2+}$ ions are advantageous properties of these enzymes to be used as additives in the detergent industry. A number of researchers have previously utilized various Bacillus strains and different cultivation media to maximize the yield of alkaline protease (Table 2).

\section{CONCLUSION}

From the above given account, it can be inferred that microorganisms, especially extremophiles, are amazing creatures which are immense sources of a variety of useful substances. Particularly, the alkalophilic protease producing bacteria which are significant contributors of biocatalysts with wide-ranging applications across several industries i.e. brewing, meat, photographic, leather, dairy, detergent, paper, and pulp, silk, food and pharmaceutical industries as well as in bioremediation processes. These enzymes are important because of their stability and ability to withstand the harsh conditions of industries. The use of protease, produced from alkalophilic bacteria, in the industry is still increasing, and there is a need to further explore the hostile environments for the isolation, characterization, and optimization of strains that give higher yields to meet with the ever-growing demands.

\section{CONFLICTS OF INTEREST}

None.

\section{FUNDING SOURCE}

None.

\section{ACKNOWLEDGMENTS}

The authors are thankful to the Vice Chancellor of the University of Okara, Pakistan for providing the platform and support.

\section{LIST OF ABBREVIATIONS}

16S rDNA Ribosomal deoxyribonucleic acid where S is Svedberg (a unit)

EDTA Ethylenediaminetetraacetic acid

LB medium Luria broth medium

NCBI National Center for Biotechnology Information

PCR Polymerase chain reaction

PMSF Phenylmethylsulfonyl fluoride

SDS-PAGE Sodium dodecyl sulfate-polyacrylamide gel electrophoresis

\section{REFERENCES}

1. Kumar R, Patel DD, Bansal DD, Mishra S, Mohammed A, Arora R, et al. Extremophiles: Sustainable resource of natural compoundsextremolytes. Sustain Biotech Springer. 2010; 27994.

2. Mesbah NM, Wiegel J. Life at extreme limits. Ann NY Acad Sci. 2008; 1125:44-57.

3. Averhoff $B$, Muller V. Exploring research frontiers in microbiology: Recent advances in halophilic and thermophilic extremophiles. Res Microbiol. 2010; 161:506-14.

4. Garrett RA, Klenk HP. Archaea: Evolution, physiology, and molecular biology. John Wiley \& Sons; 2008.

5. Gerday C, Glansdorff N. Physiology and biochemistry of extremophiles. ASM Press; 2007.

6. Oren A. Diversity of halophilic microorganisms: Environments, phylogeny, physiology, and applications. J Ind Microbiol Biotechnol. 2002; 28:5663.

7. Dickinson I, Goodall-Copestake W, Thorne MA, Schlitt T, Avila-Jimenez ML, Pearce DA. Extremophiles in an Antarctic marine ecosystem. Microorg. 2016; 4:8-15. 
8. Rampelotto PH. Extremophiles and extreme environments. Life 2013; 3:482-5.

9. Kanekar PP, Nilegaonkar SS, Sarnaik SS, Kelkar AS. Optimization of protease activity of alkaliphilic bacteria isolated from an alkaline lake in India. Bioresour Technol. 2002; 85:87-93.

10. Shivlata L, Satyanarayana T. Thermophilic and alkaliphilic Actinobacteria: Biology and potential applications. Front Microbiol. 2015; 6-13.

11. Horikoshi K. Alkaliphiles: Some applications of their products for biotechnology. Microbiol Mol Biol Rev.1999; 63:735-50.

12. Ash C, Farrow JAE, Wallbanks S, Collins MD. Phylogenetic heterogeneity of the genus Bacillus revealed by comparative analysis of small-subunitribosomal RNA sequences. Lett Appl Microbiol. 1991; 13:202-6.

13. Ali MI, Ahmad MS, Hozzein WN. WA 52-A Macrolide antibiotic produced by alkalophile Nocardiopsis dassonvilleli WA 52. Aust J Basic Appl Sci. 2009; 3:607-16.

14. Demir T, Gube O, Yucel M, Hames-Kocabas EE. Increased alkalotolerant and thermostable ribonuclease (RNase) production from alkaliphilic Streptomyces sp. M49-1 by optimizing the growth conditions using response surface methodology. World J Microbiol Biotechnol. 2013; 29:1625-33.

15. Purushe S, Prakash D, Nawani NN, Dhakephalkar P, Kapadnis B. Biocatalytic potential of an alkalophilic and thermophilic dextranase as a remedial measure for dextran removal during sugar manufacture. Bioresour Technol. 2012; 115:2-7.

16. Denizci AA, Kazan D, Abeln ECA, Erarslan A. Newly isolated Bacillus clausii GMBAE 42: An alkaline protease producer capable to grow under higly alkaline conditions. J App Microbiol. 2004; 96:320-7.

17. Nilegaonkar SS, Kanekar PP, Sarnaik SS, Kelkar AS. Production, isolation and characterization of extracellular protease of an alkaliphilic strain of Arthrobacter ramosus, MCM B-351 isolated from the alkaline lake of Lonar, India. World J Microbiol Biotechnol. 2002; 18:785-9.

18. Adrio JL, Demain AL. Microbial enzymes: Tools for biotechnological processes. Biomol. 2014; 4:117-39.

19. Sjodahl J, Emmer A, Vincent J, Roeraade J. Characterization of proteinases from Antarctic krill
(Euphausia superba). Protein Expr Purif. 2002; 26:153-61.

20. Beg QK, Sahai V, Gupta R. Statistical media optimization and alkaline protease production from Bacillus mojavensis in a bioreactor. Process Biochem. 2003; 39:203-9.

21. Singh J, Vohra RM, Sahoo DK. Purification and characterization of two extracellular alkaline proteases from a newly isolated obligate alkalophilic Bacillus sphaericus. J Ind Microbiol Biotechnol. 2001; 26:387-93.

22. Sookkheo B, Sinchaikul S, Phutrakul S, Chen ST. Purification and characterization of the highly thermostable proteases from Bacillus stearothermophilus TLS33. Protein Expr Purif. 2000; 20:142-51.

23. Gupta A, Roy I, Patel RK, Singh SP, Khare SK, Gupta MN. One-step purification and characterization of an alkaline protease from haloalkaliphilic Bacillus $s p$. J Chromatogr A. 2005; 1075:103-8.

24. Devi Rajeswari V, Jayaraman G, Rameshpathy M, Sridharan TB. Production and characterization of extracellular protease from halotolerant bacterium Virgibacillus dokdenensis VITP14. Res J Biotechnol. 2012; 7:38-43.

25. Anwar A, Saleemuddin M. Alkaline proteases: A review. Bioresour Technol. 1998; 64:175-183.

26. Mukherjee AK, Adhikari H, Rai SK. Production of alkaline protease by a thermophilic Bacillus subtilis under solid-state fermentation (SSF) condition using Imperata cylindrica grass and potato peel as low-cost medium: Characterization and application of enzyme in detergent formulation. Biochem Eng J. 2008; 39:353-61.

27. Dias DR, Vilela DM, Silvestre MPC, Schwan RF. Alkaline protease from Bacillus $s p$. isolated from coffee bean grown on cheese whey. World J Microbiol Biotechnol. 2008; 24:2027-34.

28. Gupta R, Beg Q, Lorenz P. Bacterial alkaline proteases: Molecular approaches and industrial applications. Appl Microbiol Biotechnol. 2002; 59:1532.

29. Saeki K, Ozaki K, Kobayashi T, Ito S. Detergent alkaline proteases: Enzymatic properties, genes, and crystal structures. J Biosci Bioeng. 2007; 103:501-8.

30. Cowan D. Industrial enzyme technology. Trends Biotechnol. 1996; 14:177-8. 
31. Fujiwara $\mathrm{N}$, Yamamoto $\mathrm{K}$, Masui $\mathrm{A}$. Utilization of a thermostable alkaline protease from an alkalophilic thermophile for the recovery of silver from used X-ray film. J Ferment Bioeng. 1991; 72:306-8.

32. Gupta R, Gupta K, Saxena RK, Khan S. Bleachstable, alkaline protease from Bacillus sp. Biotechnol Lett. 1999; 21:135-8.

33. Rahman RNZA, Razak CN, Ampon K, Basri M, Zin WM, Yunus W, et al. Purification and characterization of a heat-stable alkaline protease from Bacillus stearothermophilus F1. Appl Microbiol Biotechnol.1994; 40:822-7.

34. Cheng K, Lu FP, Li M, Liu LL, Liang XM. Purification and biochemical characterization of a serine alkaline protease TC4 from a new isolated Bacillus alcalophilus TCCC11004 in detergent formulations. Afr J Biotechnol. 2010; 9:4942-53.

35. Ravishankar K, Kumar MA, Saravanan K. Isolation of alkaline protease from Bacillus subtilis AKRS3. Afr J Biotechnol.2012; 11:13415-27.

36. Sen S, Dasu VV, Dutta K, Mandal B. Characterization of a novel surfactant and organic solvent stable highalkaline protease from new Bacillus pseudofirmus SVB1. Res J Microbiol. 2011; 6:769-75.

37. Tambekar DH, Dhundale VR. Studies on the physiological and cultural diversity of bacilli characterized from Lonar lake (MS) India. Biosci Discov. 2012; 3:34-9.

38. Kitada M, Wijayanti L, Horikoshi K. Biochemical properties of a thermophilic alkalophile. Agric Biol Chem. 1987; 51:2429-35.

39. Manachini PL, Fortina MG, Parini C. Thermostable alkaline protease produced by Bacillus thermoruber-a new species of Bacillus. Appl Microbiol Biotechnol. 1988; 28:409-13.

40. Fujiwara N, Masui A, Imanaka T. Purification and properties of the highly thermostable alkaline protease from an alkaliphilic and thermophilic Bacillus sp. J Biotechnol.1993; 30:245-56.

41. Uyar F, Porsuk I, Kizil G, Yilmaz El. Optimal conditions for production of extracellular protease from newly isolated Bacillus cereus strain CA15. Eurasian J Biosci. 2011; 5-14.

42. Ali SS, Habib IFFA, Riaz TANZ. Screening and characterization of alkaliphilic bacteria from industrial effluents. Univ J Zool. 2009; 24:49-60.
43. Ibrahim AS, Al-Salamah AA. Optimization of media and cultivation conditions for alkaline pro tease production by alkaliphilic Bacillus halodurans. Res $\mathrm{J}$ Microbiol. 2009; 4:251-9.

44. Pathak A, Rathod MG. Bioprospecting an alkaline ecosystem of Lonar Lake for novel alkaline protease producer. Innovative Res Chem. 2013; 1:22-6.

45. Borsodi AK, Marialigeti K, Szabo G, Palatinszky M, Pollak B, Keki Z, et al. Bacillus aurantiacus sp. nov., an alkaliphilic and moderately halophilic bacterium isolated from Hungarian soda lakes. Int J Syst Evol Microbiol. 2008; 58:845-51.

46. Verma J, Shikha D R M, Saxena S. Characterization of novel alkaline protease producing streptomyces from alkaline soil of Lucknow,(up), India. Int J Pharma Bio Sci. 2013; 4(2): 214-24.

47. Sawant R, Nagendran S. Protease: An enzyme with multiple industrial applications. World J Pharm Pharm Sci. 2014; 3:568-79.

48. Seifzadeh S, Hassan Sajedi R, Sariri R. Isolation and characterization of thermophilic alkaline proteases resistant to sodium dodecyl sulfate and ethylene diamine tetraacetic acid from Bacillus sp. GUS1. Iran J Biotechnol. 2008; 6:214-21.

49. Johnvesly B, Naik GR. Studies on production of thermostable alkaline protease from thermophilic and alkaliphilic Bacillus sp. JB-99 in a chemically defined medium. Process Biochem. 2001; 37:139-44.

50. Gessesse A, Hatti-Kaul R, Gashe BA, Mattiasson BO. Novel alkaline proteases from alkaliphilic bacteria grown on chicken feather. Enzyme Microb Technol. 2003; 32:519-24.

51. Joo HS, Chang CS. Production of protease from a new alkalophilic Bacillus sp. I-312 grown on soybean meal: Optimization and some properties. Process Biochem. 2005; 40:1263-70.

52. Patel R, Dodia M, Singh SP. Extracellular alkaline protease from a newly isolated haloalkaliphilic Bacillus sp.: Production and optimization. Process Biochem. 2005; 40:3569-75.

53. Ibrahim AS, Al-Salamah AA, El-Badawi YB, El-Tayeb MA, Antranikian G. Detergent, solvent-and saltcompatible thermoactive alkaline serine protease from halotolerant alkaliphilic Bacillus sp. NPST-AK15: Purification and characterization. Extremophiles 2015; 19:961-71. 
54. Horikoshi K. Production of alkaline enzymes by alkalophilic microorganisms. Agr Biol Chem. 1971; 35:1783-91.

55. Takii $\mathrm{Y}$, Kuriyama N, Suzuki $\mathrm{Y}$. Alkaline serine protease produced from citric acid by Bacillus alcalophilus subsp. halodurans KP 1239. J Microbiol Biotechnol. 1990; 34:57-62.

56. Van Putten AB, Spitzenberger $F$, Kretzmer $G$, Hitzmann B, Schugerl K. On-line and off-line monitoring of the production of alkaline serine protease by Bacillus licheniformis. Anal Chim Acta. 1995; 317:247-58.

57. Singh J, Vohra RM, Sahoo DK. Enhanced production of alkaline proteases by Bacillus sphaericus using fed-batch culture. Process Biochem. 2004; 39:1093101. 